\title{
UNDEMOCRATIC CENTRALISM AND NEO-CORPORATISM: THE NEW BRITISH CONSTITUTION
}

\author{
NORMAN LEWIS*
}

Professor Lewis argues that Britain's lack of a constitutionally entrenched bill of rights, combined with the failure of the English courts to sufficiently protect individual rights and interests, has served to create a void of adequate protections for those freedoms which are seen as being fundumental to a parliamentary democracy. Furthermore, the author argues that the parliamentary system of govermment in Britain has devolved from a forum of rational discourse, into a party system, and more recently into a quasi-presidential system where ultimate power lies with the Prime Minister. The devolution of the parliamentary system, when combined with the lack of adequate protections of civil liberies, is seen as creating a system of "undemocratic centralism", examples of which are provided. These factors, Professor Lewis argues, are indicative of Britain's need of a more adeguate system of checks and balances, and a Charter of Rights similar 10 Canada's, each of which can be achieved by a new Constitutional "settlement".
Selon le Professeur Lewis, le fait que l'Angleterre $n$ 'a pas de charte enchâssée dans sa constitution et que les tribunaux anglais ne réussissent pas à protéger efficacement les droits et intérêts individuels, a créé une situation de carence où ne sont pas suffisamment protégées les libertés que l'on estime fondamentales d̀ une démocratie parlementaire. Plus encore, anciennement lieu de débats motivés par la raison, le système est tombé dans une politicaillerie de partis, et plus récemment, dans une pratique quasi-présidentielle où le pouvoir ultime est entre les mains du Premier Ministre. En l'absence de protection adéquate des droits de la personne, cette dévolution du système parlementaire est montrée, exemples à l'appui, comme aboutissant d̀ un système de "centralisme antidémocratique". Ces facteurs démontrent que l'Angleterre a besoin d'un système efficace d'équilibre des pouvoirs et d'une Charte des droits et libertés semblable d celle du Canada; chacun de ces deux objectifs pourraient se réaliser au moyen d'une "entente" constitutionnelle.

TABLE OF CONTENTS

I. INTRODUCTION

II. THE 'SETTLED BRITISH CONSTITUTION' $\ldots \ldots \ldots \ldots \ldots, 541$

III. 300 YEARS: A LONG TIME BETWEEN REVOLUTIONS . . 542

IV. UNDEMOCRATIC CENTRALISM $\ldots \ldots \ldots \ldots \ldots \ldots \ldots, 543$

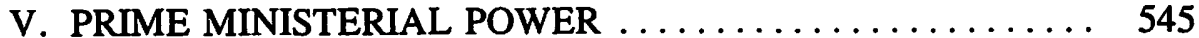

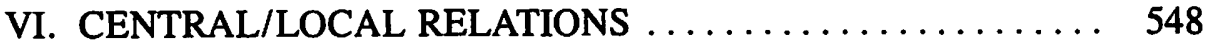

VII. NEO-CORPORATISM AND THE CONSTITUTION . . . . . . 549

VIII. CONCLUSIONS $\ldots \ldots \ldots \ldots \ldots \ldots \ldots \ldots \ldots \ldots \ldots, \ldots 52$

\section{INTRODUCTION}

I have argued elsewhere that the British Constitution has been increasingly undermined in recent times.' That this has gone either unremarked or unchastised is partly because the canons of the constitution are largely non-justiciable and partly because an intensification of the process of centralisation has made the manipulation of popular ideology that much easier.

The centralisation has been made possible for reasons which cannot be fully developed here although it has been increasingly remarked that Britain, a Parliamentary monarchy, enjoys what in effect amounts to a strong presidential system of government. It is interesting to note, for example, that the United States, perhaps

* Co-Director, Centre for Criminological and Socio-Legal Studies, The University of Sheffield, U.K.

1. I. Harden and N. Lewis, The Noble Lie: The British Constitution and the Rule of Law (London: Hutchinson, 1986). 
the archetype of a presidential system, limits its presidents in the normal course of events to an eight-year, two-term period of office. Our own Prime Minister is now, of course, in her eleventh year of office and her third period of government. There is nothing formally preventing her from continuing until well into the twentyfirst century.

As is so often true of the British experience, our successes tend to be our failures and our strengths our weaknesses. A period of remarkable social and political stability, rightly the envy of much of the free world, has often meant that our social and industrial structures have not been re-addressed to take account of changed circumstances. Instead, new wine has frequently been poured into old bottles with a considerable amount of spillage and corkage. Nowhere has this been truer than of Parliament itself, at one time the clear voice of representative rational discourse. I risk here collapsing a number of different developments at the necessary expense of subtlety but it is almost certainly true to say that the relative demise of Parliament as a cogent influence on the decision-making process was directly associated with the growth of the Party system. But I anticipate myself. A return to the period of the seventeenth century settlement is perhaps called for.

\title{
II. THE 'SETTLED BRITISH CONSTITUTION'
}

If we can identify the 'settled' British constitution at all, then it is at and around the time of the Glorious Revolution. We must include in this characterisation the Act of Settlement of 1701. The two central features were to be an open and representative Parliament, or at least a House of Commons, and a judiciary with independence and legal autonomy. Much of what follows is shorthand since, for example, Parliament was not representative in any very democratic sense at that time, while publication of its proceedings was still regarded as a breach of Parliamentary privilege. Nonetheless, not only was Parliament representative (of certain interests), but its members enjoyed privileges which allowed them to argue for their beliefs in open and free assembly and to demand answers to questions. As Holdsworth put it: ${ }^{2}$

\begin{abstract}
. . the procedure of the House of Commons helped to make the House representative of all the politically conscious classes of the nation, and to keep it in touch, throughout the century, with the public opinion of the day . . . Because this system of procedure made it possible for the advocates of reforms to get a hearing, to convert Parliament, and so to effect necessary reforms in a constitutional manner, it preserved the national pride in Parliament, and in the constitution of which Parliament was the centre.
\end{abstract}

The argument has been well put in a Canadian setting by Rand J. in Switzman v. Elbling ${ }^{3}$ when he said that parliamentary government was "ultimately government by the free public opinion of an open society" and that it demanded "the condition of a virtually unobstructed access to and diffusion of ideas".

Once the judiciary had secured effective independence, then another major blow had been struck. What more rational and intellectual forum was there than a court of law where argument was sustained through evidence and proof, and where rebuttal was subject to the same laws of discourse? A reasoned decision based upon

2. A History of English Law, vol. X (London: Methuen, 1903) at 538.

3. [1957] S.C.R. 285 at 358. 
evidence subject to rigorous testing was the product of an official independent of both the Crown and factional interests.

The picture then was, at least at the surface level, one of a nation united under a constitution which boasted freedom of discussion and clear lines of responsibility for action taken. The newly-independent judiciary administered the Common Law which was generally taken to be the embodiment of the cultural belief system of the people at large. The judges became the trustees of the Common Law compact whose principles would not only be watered down but would be allowed to flourish in the face of each new development. Parliament, for its part, would normally not encroach upon the Common Law except after a full debate which took account of all salient interests. Let us take this picture as ideal-typical since it was not only Cromwell's public image that was disfigured by warts. However, warts and all, this broad picture constituted the legitimation foundations of the new state. Crucially, it is against this picture that constitutional reality has to be judged, both then and now. The rhetoric remains much the same. The rule of law at base depends fundamentally on the twin pillars of the constitution whose essential nature is as here outlined.

\section{300 YEARS: A LONG TIME BETWEEN REVOLUTIONS}

What has altered, of course, is the site of public power and the consequent alteration in the role of the judiciary. The eighteenth century judiciary operated in an atmosphere where government was night-watchman, the nineteenth and twentieth century judiciary in one where governments of both right and left have been, and remain, highly interventionist in various ways. The Common Law then has been constantly overriden and the judges left with little to do in the field of constitutional law except to hold government to its promises, both precise and imprecise. That is to say, they interpret detailed legislation in a substantially literal fashion and discretionary powers in a disinterested fashion. If Parliament/government gives itself imprecise powers then imprecise powers are what it can exercise. The Common Law has largely ceased to be a libertarian bulwark and, in so far as it possesses inner meaning, then that relates largely to the canons of private law untrammeled by entrenched civil liberties.

The power of Parliament was at its zenith early in the eighteenth century and has been diminishing ever since. The analysis here is again a crude overview, but the development of the party system and party politics sees the ancient power of Parliament seriously on the wane. It is important to remember in this respect that the growth of party is simply another convention, unencumbered by constitutional regulation so that appearances are preserved (i.e. Parliament exercises ultimate power) while the real world has changed out of recognition. The trick is for Parliament to be beholden to the dominant party or, more properly, the leader of that party. It has therefore become commonplace to say that Britain is governed through Parliament but not by Parliament. As Professor de Smith has indicated, the House of Commons gives the government a legitimation foundation. ${ }^{4}$ It is quite remarkable how little this fact is understood by the ordinary British public.

4. S.A. deSmith, Constitutional and Administrative Law (London: Penguin, 1971), c. 1-3. 
Let me attempt a summary. The 'English Revolution' was based upon institutions whose ideal nature was characterised by rational discourse. Over time the power of the institutions waned and passed to other sites, while the constitutional pretence remained that power was exercised as formerly. The result has been a lack of attention being paid to the canons of rational discourse, and the failure of open debate within the presently powerful sites of decision-making.

What remains is to discuss the geography of effective public power within the British state; the locus of effective decision-making.

\section{UNDEMOCRATIC CENTRALISM}

The centralisation of power within the British state was perhaps first systematically remarked upon by Bagehot, albeit with some approval..$^{5}$ It was he, above others, who taught us to look at the cabinet as the power-house of government policy-making. Since that time centripetal tendencies have grown apace though I only make a few brief references here. The First World War gave especial impetus to centralised decision-making, turned into an art-form by David Lloyd-George and catalogued painstakingly by Professor Middlemas. ${ }^{6}$ The cabinet secretariat effectively dates from that period and, as has been observed elsewhere, power once gained is rarely relinquished. The Second World War merely exacerbated the trend, and the obsession with economic management of successive governments has ensured the domination of government at the centre. In more recent years cabinet committees (still formally rendered out of bounds as a constitutional topic by the Official Secrets Act) have caused even the cabinet itself to take second-place as a decision-making site. Sir Douglas Wass, former joint head of the home civil service, has remarked that cabinet has become an unsuitable mechanism for the effective discussion of policy issues. ${ }^{7}$ More recently, Lord Hailsham, in a series of journalistic statements, has remarked upon the concentration of power in cabinet committees during the successive Thatcher administrations. ${ }^{8}$

All this has long been understood by political scientists. Unless checks and balances were deliberately engineered into place to broaden and democratise the decision-making process, the tendency was bound to gather momentum. So it has proved in the last decade. The increasingly presidential style of Mrs. Thatcher has been brought to bear upon constitutional machinery which had always been susceptible of a centralist takeover. For example, the awesome power of patronage possessed by British prime ministers is unencumbered by anything resembling the U.S. Federal Advisory Committees Act $1972^{9}$ or the veto powers possessed by the American Senate. In the past, both conventions and Conventions, as well as a general culture of civility, were thought to be sufficient safeguards against partisan abuse. After all, it is common ground that a respect for civil liberties may be

5. W. Bagehot, The English Constitution (London: Collins, 1963).

6. K. Middlemas, The Politics of Industrial Society: The Experience of the British System Since 1911 (Rowman \& Littlefield, 1979).

7. Government and the Governed (London: Routledge \& Kegan Paul, 1983).

8. See, for example, "The Future of Cabinet Government" (1987) 2 Const. Ref. 1.

9. 5 U.S.C.S., Appx. I. 
as securely depended upon through a tradition of tolerance as through distinctly legislative measures: ${ }^{10}$

Tolerance of political and religious dissent, and of racial and linguistic minorities, freedom of movement, control of police powers, and fair and open trials are among the criteria by which a nation's record is judged.

Now it would be manifestly absurd to argue that these guarantees have been swept away in Britain. Even so, an insidious process of erosion has nonetheless been occurring. Tolerance of political dissent is certainly not what it was, while Britain's record in protecting minorities has been constantly challenged, with some little success, before the European Court of Human Rights. Furthermore, the control of police powers has been shown in recent times to be highly unsatisfactory, with a de facto movement towards a national police force being unaccompanied by a revised system of accountability." In short, most political and constitutional commentators would now accept that many of the old accords have been largely swept aside. New legal safeguards have not been prayed in aid, with the result that it falls to the judiciary to be increasingly vigilant in protection of the rule of law. I shall have more to say on this matter shortly, but it is doubtful if a coherent judicial awareness of constitutional needs can be awakened at such a late stage without strong political support.

In this respect particular mention should be made of the Official Secrets Acts and the other accompaniments of state security law. The Peter Wright, or 'Spycatcher', case has naturally received the main charge of publicity, ${ }^{12}$ but one must not overlook the prosecutions of either Sarah Tisdall or Clive Ponting. Indeed, the acquittal of Ponting, after what amounted to a virtual instruction to convict by the trial judge, led in the short term, to the Law Officers relaxing their reliance on criminal prosecutions, in favour of the [developing] civil law of confidentiality. It soon became clear that the Government intended to impose a life-long oath of silence on members of the secret services at the very least. This was soon evidenced in the case of Attorney-General v. $B B C$ where an injunction was obtained to ban a television programme which had been cleared by the chairman of the compliant D-notice Committee, a largely self-disciplining body of journalists. ${ }^{13}$ The terms of the injunction were such as to impose a duty of confidentiality not only on members of the services themselves, but also on anyone to whom they communicate confidential information. Now, it is understandable that any government should be sensitive to the very special requirements of the security services, but what is unique in the British case is the insistence that the duty is unqualified, that it bends to no higher duty (e.g. the maintenance of the ground-floor democratic conditions), and that ministers rather than judges shall be the determiners of the public good.

In early 1988 the Government continued its commitment to closed politics by ordering a three-line whip against supporting one of its own backbencher's private member's bill to reform the Official Secrets Acts in circumstances where a 'public interest defence' would have been afforded. The position at criminal law, however, is now governed by the Official Secrets Act $1989^{14}$ which abolished the infamous

10. P.W. Hogg, Constitutional Law of Canada, 2nd ed. (Toronto: Carswell, 1985) at 631.

11. See, for example, L. Lustgarten, The Governance of Police (London: Sweet and Maxwell, 1986).

12. Attorney-General v. Guardian Newspapers, [1988] 3 All. E.R. 545.

13. See The Guardian, December 18, 1987.

14. (U.K.), 1989, c. 6. 
section two Official Secrets Act $1911^{15}$ and thereby effected what may be interpreted as a mild improvement. However, life-long duties of secrecy remain both for members of the security services and crown servants more broadly, though the nature of the duties imposed varies somewhat as between the two categories. Furthermore, the criminal law is not the end of the matter since it is clear that the Government intends to tighten up the terms and conditions of employment of crown servants while the developing law of confidentiality remains unaffected by the Act. Even so, it will be interesting to see whether the European Court of Human Rights will be satisfied, when a challenge to the Act is mounted, that Britain provides "adequate and effective safeguards against abuse"16 of Article 10 of the Convention which seeks to safeguard freedom of expression.

As a rider, it might be added that, in spite of general opinion to the contrary, section two Official Secrets Act 1911 did afford the judiciary the opportunity to display an understanding of the underlying constitutional claims which the Revolution of 300 years ago proclaimed. An offence was not committed by anyone who communicated information either to "a person to whom he is authorised to communicate it, or a person to whom it is in the interests of the State his duty to communicate it". It is only by equating "the state" with the prime minister that the section was seen to be as rhadamanthine as it was generally assumed to be.

\section{PRIME MINISTERIAL POWER}

Most recently, the Prime Minister has not only taken personal charge of a number of vitally important cabinet committees herself, but has also engaged in highpowered informal meetings or 'seminars' with salient industrial and commercial figures at Downing Street. To take just two examples. In the Autumn of 1987 the Prime Minister was reported to have taken personal charge of a small cabinet committee whose remit was to produce a blueprint for a Protection of Official Information Bill to replace the Official Secrets Acts. Just a little earlier she had called in leading figures in the world of broadcasting to a 'seminar' on the future of broadcasting. The Peacock enquiry had, of course, previously been instructed to investigate these matters, but the idea that the majordecisions on such an important aspect of public life could be taken effectively by one person after a five-hour discussion beggars description. The imperious nature of this particular gesture will not be lost on a Canadian audience.

Two more matters of vital importance need to be addressed in order to see how far implicit constitutional assumptions have been subverted. The first concerns the attempt to construct an ideologically sound citizenry. The second concerns the relative dismemberment of local government; this pincer movement takes us not only further towards a presidential system of government but towards a unitary state of the sort not considered acceptable in recent political history.

These two strains are carefully interwoven and, probably, interdependent. The construction of acceptable world-views and the marginalisation of others has been occuring in defiance not simply of former political understandings, but in defiance

15. (U.K.), 1911, c. 28.

16. See Leander v. Sweden, The Times 25, 1987; [1987] C.L.Y. para. 1919 (European Court of Human Rights). 
of constitutional principles. We are speaking here to matters of a constitutional nature and not simply of political preference. Not only are particular points of view being rendered unacceptable but the opportunity to debate alternatives is being seriously jeopardised. There are many illustrations of this trend, but the imposition of a 'common core curriculum' for schools and their ability to 'opt out' of local government control is as good an example as any. The imposition of a common core curriculum, announced in the Education Reform Act $1988,{ }^{17}$ not only compels schools to follow particular lines of education and, to a considerable extent thereby, instruction, but simultaneously limits the opportunity to teach subjects or topics outside the curriculum. Section four of the Act gives the Secretary of State power to make orders relating not only to subjects of study but to "such programmes of study" as he considers appropriate. Furthermore, he is given enormous powers of direction and control which are unprecedented in our times. The social sciences will be the sufferers in general and, for example, peace studies in particular. It is also instructive to note that the primary funding agency for social science in the tertiary educational sector, the former Social Sciences Research Council, has been renamed the Economic and Social Research Council. Pluralistic debate about the social world cannot be scientific. The study of economics, now first among equals apparently, can nevertheless remain scientific in light of later events, provided always that it follows the 'laws' of the market.

These events are not isolated. Indeed, if they were, there would be less point in remarking upon them. It is still too early to understand the full impact of the proposed University Funding Council, which is to replace the present University Grants Committee, probably in early 1989 . This Body, whose appearance was also announced in the Education Reform Act ${ }^{18}$ springs into life at about the same time that the Government is removing the secure tenure of University staff. Furthermore, it is clear that it is to be much more heavily influenced by the representatives of industry and commerce than was formerly the case, with the result that the academic community will be placed under severe pressure in seeking to preserve its traditional role. Indeed the same fears must be expressed about the various curriculum and assessment councils which the Secretary of State has established for primary and secondary schooling. Originally the Bill had spoken of these councils having ten to fifteen members (appointed solely by the Minister) with no more than two needing to have "relevant knowledge or experience in education". In passing through the House the provision was amended merely to ensure that the Councils shall include "persons" with educational experience. Any lawyer will readily understand that "persons" need not amount to more than two. One does not have to dispute the bona fides of the industrial world to entertain fears about the relative weight which might be paid to 'pure', a priori research as opposed to that with a short-term technological payload, or to "vocational" as opposed to "academic" study within schools. A final point to be made on this score is that where 'social' research is commissioned by the Government there is now some movement to suppress those findings which are unpalatable in the interests of retaining the purity of governmental ideological messages. The former Department of Health and Social Security spearheaded this particular development.

17. (U.K.), 1988, c. 3.

18. Ibid., s. 131. 
It is difficult to overestimate the seriousness of this trend. It is a part of the same denial of the constitution which I have spoken to earlier. The traditional accords, based upon the fundamental rational discourse requirements of the seventeenth century settlement encouraged pluralism, encouraged 'eccentricity' and to an extent even was tolerant towards 'provincialism'. Slowly, formal constitutional omnicompetence has been harnessed to give massive ideological power to ruling party factions. It is little wonder that the European Court of Human Rights is looked upon with greater enthusiasm than formerly by opposition groups within and outside Parliament. There is now no doubt in my mind that entrenched constitutional guarantees about the nature of citizenship, and most forcefully freedom of expression both atomistically and institutionally, are sorely needed.

One of the more blatant attacks on freedom of expression, and which was given much publicity at the time, is to be found in section 28 Local Government Act $1988 .{ }^{19}$ As a result of some spectacular scaremongering, which was never given substance in any public statement, it is now unlawful to "promote the teaching in any maintained school of the acceptability of homosexuality as a pretended family relationship'. Similarly it is an offence intentionally to promote homosexuality. At the time of writing no case had been brought before the courts but government spokesmen have made it clear that the expression of a view that homosexuality is in any way 'normal' would be covered by the legislation. We should of course be reminded that homosexual acts committed in private by consenting adults has been lawful in Britain since $1967 .{ }^{20} \mathrm{~A}$ balancing provision intended to underwrite the freedom of speech/expression of schoolteachers has been found to be beyond the competence of the parliamentary draftsmen, in spite of the fact that section 43 of the Education (No. 2) Act $1980^{21}$ found a suitable form of words to promote freedom of speech within our Universities. The University administrations are under a duty, so far as is "reasonably practicable" to ensure freedom of speech on campus. Why on campus and not in the media or the cloisters of government itself is not explained. It is perhaps worth noting, however, that denial of expression in University student unions, a deplorable practice in most cases, has traditionally been directed at speakers representing the political 'right'. The Guardian Newspaper, referring to the homosexuality provision, in perhaps uncharacteristically forceful fashion, has labelled the move as both amounting to the persecution of a minority and an exercise in "state indoctrination". ${ }^{22}$ Moreover, sections 17 and 18 of the same Act severely limit the ability of local authorities to include in contracts numerous provisions which they believe would foster improved race relations. For example, insisting on breaking off dealings with South Africa is now illegal in such a context while even insisting on the racial bona fides of those who tender for contracts has been severely circumscribed. In the past such moves would have resulted in the most fervent public debate and heartsearching, with the mobilisation of opposition from a number of establishment quarters. With 'the establishment' now populistly derided, the absence of an entrenched Bill of Rights is more keenly felt than ever. It ought to be added, for the sake of completeness, that the courts have contributed little in this area which would embarrass central govern-

19. (U.K.), 1988, c. 9.

20. See The Sexual Offences Act, 1967 (U.K.), 1967, c. 60, s. 1.

21. (U.K.), 1986, c. 61.

22. The Guardian, December 14, 1987. 
ment. In two contentious decisions they have declared the policy of local authorities in seeking to combat apartheid to be ultra vires. ${ }^{23}$

In most cultures other than the British, it would be normal for a Professor of Constitutional Law to speak to these issues and to express concern; to point up the challenge to the ancient ideals of the rule of law. Instead, I suspect that I shall be accused of talking politics rather than law, a response which is the first refuge of the legal positivist. It is only because the 'rule of law' is not examined against the background for which Ian Harden and I argued in The Noble Lie that such a defence of the indefensible is possible. When collective rational discourse (the foundationstone of a parliamentary democracy, as I must continue to stress) filters down to the protection of the basic civil liberties then this becomes much easier to see. Freedom of expression, in other words, is one and indivisible.

As Peter Hogg has said, one of the broader rationales for the constitutional protection of freedom of expression is its role as an instrument of personal fulfillment. ${ }^{24}$

On this theory, which is to be found in some American judicial decisions, expression is protected not just to create a more perfect polity, and not just to discover the truth, but to "enlarge the prospects for self-fulfillment", or to allow "personal growth and self-realization". If expression is conceived in these broad terms, it covers much that is not speech at all; an, music and dance, for example.

He goes on to point out that American courts have accepted a variety of forms of "expressive conduct" as being "symbolic speech", which is entitled to first amendment protection. For example, a refusal to salute the flag, the desecration of a flag, the burning of a draft card, and the wearing of a black armband. ${ }^{25}$

Now in Britain the position concerning the courts and their protection of "constitutional" rights has long been clear. No-one has sought to refute the proposition advanced by Humphreys J. in Duncan v. Jones ${ }^{26}$ that no constitutional principle is involved when interpreting a statutory offence of obstructing a police officer in the course of his duty, even though the issue of freedom of political expression was at centre stage. Constant vigilance has been practised in assessing the issue of freedom of speech and public order in the years that have elapsed, even if the latter has been afforded general pre-eminence over the former in practice. As to the subtler issues of non-conformity, however, it has always been assumed that the political arena would afford adequate protection. Given that I wish to argue that such assumptions have been strenuously opposed in recent years, it follows that only legally enforceable guarantees concerning freedom of expression can ensure that discourse over the balance of order versus personal fulfillment remains on the public agenda.

\section{CENTRAL/LOCAL RELATIONS}

What of the position of local government? Again, this is not the place to catalogue the diminution of the powers of elected local government members over

23. London Borough of Lewisham v. Shell U.K. Ld., The Guardian, December 22, 1987, following Wheeler v. Leicester City Council [1985] A.C. 1054.

24. Supra, note 10 at 714 .

25. lbid.

26. [1936] 1 K.B. 218. 
recent years but the process has been constant and unrelenting. The third term of the Thatcher government has increased the momentum of this development by undermining the now traditional responsibilities of local government in the field of the provision of educational and housing services.

A word or two on each of these items must suffice, though the legislation introduced for their enactment is extremely complex. First, education. Section 36 Education Reform Act $1988^{27}$ allows the delegation of a school budget to a governing body of management. That body in turn may sub-delegate to the headmaster. More dramatic still, however, are the provisions in Part IV of the Act to transfer the school from the local authority to the governing body on a simple majority vote of the parents of the children for the time being. The implications of such a move are enormous and even now little appreciated by the public at large. In this respect they share much with the provision of the Housing Act $1988^{28}$ which gives the Secretary of State power to transfer housing from local authority landlords to 'Housing Action Trusts' whose composition is, of course, for the Secretary of State to decide. Furthermore, the Act contains provisions for tenants to switch their landlord from a local authority housing department to an "approved" landlord. The whole operation will take place within a context of higher rents for the poorer classes in the community and a much higher profile for private investment schemes in the provision of housing 'outside' the public sector. In fact, the situation is such that the public/private divide is even more blurred than formerly but where hidden public subsidies are not matched by public law controls of institutional accountability.

These far-reaching measures are justified on the grounds of giving government back to the people in the form of parent-power, headmaster power, the power of the thrusting entrepreneur, and increased 'privatisation'. Whatever the apparent justification for these developments, there is occurring a replacement of elected local government representatives by other groups, largely unelected, and by 'the market', regulated inconsistently and with limited powers of legal supervision. The dramatic move of power towards unregulated markets and lightly regulated quasi-autonomous bodies operates in stark contrast to much of the public and administrative law regulation of both the civil and the common law world. Not only is Britain once more an aberrant case in this regard but is becoming more aberrant by the hour.

Although there is a clear movement towards centralisation, it is a fact of modern life that no centralised administration can effectively run social systems unaided. The problems of inadequate information, (only partly remediable through market mechanisms), inadequate resources, and 'rationality' crises means that governments in general must recruit the private and/or voluntary sector as a partner in the business of governing. To this I now briefly turn.

\section{NEO-CORPORATISM AND THE CONSTITUTION}

Various forms of 'associative conduct' are recognisable as part of the art of governing across the developed world. Government governs by a number of

27. (U.K.), 1988, c. 40.

28. (U.K.), 1988, c. 50 . 
different mechanisms and will strive to select the one most suitable for a particular task or tasks. Sometimes government ownership or participation is preferred, sometimes government regulation, sometimes 'pure' markets (though they are increasingly difficult to identify) and sometimes by a spectrum of devices which associate the public and private sectors in common schemes. This latter phenomenon can take numerous forms but I only wish to speak briefly here to that of corporatism. Again, I simplify inevitably under the circumstances. Broadly speaking, corporatism or neo-corporatism (to distinguish it from its Fascist predecessors) is a system of government intervention whereby tasks thought to be essentially govemmental are constructed or implemented by a process of bargaining between public and private actors. The criteria normally adopted to separate corporatism out from looser arrangements are some measure of institutional stability, genuine advantages accruing to both sides of the relationship, and a degree of 'delivery' of the membership of the private partner to carry out the bargained arrangements.

I have spent a great deal of time charting these developments elsewhere, ${ }^{29}$ but let me say at once that they are almost certainly a necessary feature of modern governments, both on the left and the right, though they are normally identified in particular with Scandinavia, Austria and Holland, even if Canada is often strongly bracketted with them. They may be associated with the planned growth of incomes, with training schemes, with industrial efficiency, with the maintenance of the physical infrastructure, or with schemes of social welfare. In Britain, in the past, the active cooperation of a wide range of interests has been sought to further what is regarded as in the public interest, and although this has necessarily continued under the Thatcher administrations, there is an increasing tendency to use those sites of intermediation for policy delivery which are most sympathetic to the Thatcher world view or ideology. Corporatism requires constitutional address, whatever form it takes, as do other forms of associative conduct, a matter recognised in Canada as elsewhere. For instance, in late 1987 the Law Reform Commission of Canada produced a consultation paper entitled Towards a Modern Federal Administrative Law $^{30}$ in which it considered, inter alia, the role of a revised administrative law in relation to the problems of bargaining and negotiation between "the administration" and other actors. These issues then raise questions of considerable constitutional significance at large. However, they become exacerbated, in my view, when public/private articulations are selective and where policy formation and implementation is mediated increasingly only through agents sympathetic to one particular political viewpoint. Let me turn to these matters very briefly.

All governments require good relationships with the business community but recent British governments have given certain sections of that community a preeminent position in public policy interventions. Leaving aside the highly controversial programme of privatisation of public assets, which poses major constitutional problems in itself, ${ }^{31}$ more subtle processes are at work. Even the duty of consul-

29. P. Birkinshaw, I. Harden and N. Lewis, Government by Moonlight: the Hybrid Parts of the State (London: Hyman-Unwin, 1990).

30. (Ottawa: Law Reform Commission of Canada, 1987).

31. See C. Graham and T. Prosser, "Privatising Nationalised Industries: Constitutional Issues and New Legal Techniques" (1987) 50 Mod. L. Rev. 
tation of interests has become partial, in contradistinction to those countries, like the U.S.A., which possess general-purpose statutes addressing the issue. So, for example, section 13 Rates Act $1984^{32}$ imposes a duty upon local government to consult commercial ratepayers about its proposals for annual expenditure. The nature of that information has been spelled out by the Secretary of State in regulations ${ }^{33}$ which are largely directed to linking local industrialists to the government's dislike for increased social expenditure by local authorities. Consultation is, of course, a public ' good"', but such selectivity is difficult to justify except on a partisan level. Other developments are even more partial in their replacement of public initiatives through elected bodies by a combination of central government/private initiatives, whether in the form of Urban Development Corporations, Enterprise Zones, or more recent highly corporatist interventions. Just a few examples must suffice for present purposes. In November 1987 the announcement was made of six national teams comprising some of Britain's leading businessmen to co-ordinate a range of urban renewal initiatives and to encourage private sponsorship. This was in response to a call by the Prime Minister for more private funding to revive the inner cities. This will take place with various levels of government support but the impetus for policy decisions will be private-industry based, in conjunction with whatever central government directives are thought necessary. The English Estates Corporation, a little-known state agency responsible for factory building and commercial development is also heavily involved in the new city regeneration schemes and is closely articulated with Business in the Community, a consortium of business organisations which promotes new initiatives through government tax incentives and other state benefits. My last example concerns jobtraining, an area where the private and public sectors are inextricably intertwined, and where some distinctly ideological developments are going hand in hand with training programmes administered increasingly with the assistance of local Chambers of Commerce and other industrial and voluntary training bodies. ${ }^{34} \mathrm{At}$ the time of writing the Government is examining the establishment of 'TECs' (Training and Education Councils), which will be established on an area basis and run by consortia of businessmen who will be heavily financed by central government to train their own workforce. The composition of the Councils will be overwhelmingly business-oriented. ${ }^{35}$

I have taken the view elsewhere that corporatism poses major problems of accountability; i.e. of constitutionality. There have been some improvements in recent times ${ }^{36}$ but by and large the corporatist landscape is bereft of legal methods of rendering an account. The bargains are struck too often in private without full democratic debate and the methods of monitoring and registering protests against decisions taken are largely informal and unsystematic. This would be my view regardless of the ends being pursued in the public name, or the agencies chosen for cooperation with governmental aims. What, however, causes me the greatest

32. (U.K.), 1984, c. 33.

33. Industrial and Commercial Ratepayers (Consultation) Regulations 1984, S.I. 1984/1355.

34. See, for example, The Guardian, November 19, 1987.

35. U.K., Department of Labor, Employment for the 1990's (London: H.M.S.O., 1988).

36. I would particularly identify the Parliamentary and Health Services Commissioners Act 1987, (U.K.), 1987, c. 39 which, inter alia, extends the jurisdiction of the Parliamentary Ombudsman to a considerable number of 'non-departmental public bodies'. 
concern is the combination of corporatist unaccountability with the fostering of policies designed to marginalise debate about the acceptability of the world which is in the process of being created. They are intimately connected but raise two separable issues for constitutional lawyers. To these I now very briefly turn.

\section{CONCLUSIONS}

Without speaking to the kind of changes which are necessary for the constitution at large to honour its implicit promises (again a matter to which I have spoken extensively elsewhere), both neo-corporatist networks and the encroachment upon pluralistic debate need to be addressed by the legal system. As to the former, the problem is basically one of sunlight or sunshine. Freedom of information apart, no doubt a necessary precondition for any legal order to be entitled to regard itself as democratic at the core, Britain urgently needs Government in the Sunshine legislation, the opening up of the advisory committee system where much corporatist bargaining takes place and much else besides. In particular, we require a general mechanism for registering grievances against the state in all its forms, and a system of checks and balances in relation to the potential abuse of power through the use of patronage.

As to the attack on pluralistic debate, it is clear that the common law courts will no longer replicate either Somersett's Case Cr $^{37}$ ortinck v. Carrington ${ }^{38}$ unaided, let alone develop those strains inherent in the old common law which sought to protect the individual qua individual against intrusions by the state. Indeed, the record of the British courts in this respect is nothing like as good as many commentators would have us believe. Although canons of statutory interpretation have been fashioned to prevent, for example, the surreptitious raising of taxation without the express approval of Parliament, no such presumption against interference with civil liberties has been developed. ${ }^{39}$ There have, it is true, been occasional rays of light, as for example in the case of $R \mathrm{v}$. Secretary of State for the Home Department ex.parte Khawaja. ${ }^{40}$ However, for every case 'pro', one can find six 'con'. One thing is clear; our record of restraining the executive from heavy-handedness pales into insignificance when compared to that of the Conseil D'État. ${ }^{41}$ The British courts were offered a major opportunity to claw back some of the rule of law losses of the last century in their hearing of the Spycatcher case. Whereas the decision came as an embarrassment to the Government, there is little in the judgments which indicates a bold striking out in search of greater citizen rights against the state. In any event, the force of events has taken us too far to expect or to demand from the judiciary the creation of a systematic body of constitutional and administrative doctrine which must accompany any reformulation of the rule of law. The rapidity with which the new Official Secrets legislation was introduced is a further reminder of the unsatisfactory nature of the present British constitution.

37. (1772), 20 State Tr. 1.

38. (1765), [1558-1774] All. E.R. 41.

39. Supra, note 10 at 631 .

40. [1983] 2 W.L.R. 606.

41. See, for example, Cons. d'État, 28 May 1954, Barel and Cons. d'État, 27 May 1983, Ministère des affaires sociales c. Cajarville. 
Above all else, if politics is to be conducted in a rational and humanistic fashion, we must not allow the projection of one world view at the expense of all others. To this end, it is high time that Britain paid serious attention to the experience of Canada through its Charter of Rights. Even if we are reluctant to learn from the Civil Law systems, there can be no excuse for shunning the experience of our Common Law colleagues in respect of their experiences in bringing the rule of law up to date. 